Article

\title{
Expression of Stress-Mediating Genes is Increased in Term Placentas of Women with Chronic Self-Perceived Anxiety and Depression
}

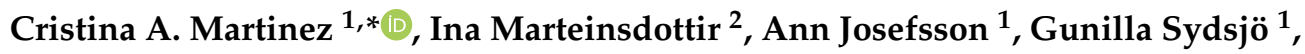 \\ Elvar Theodorsson ${ }^{3}$ and Heriberto Rodriguez-Martinez ${ }^{1}$ (D) \\ 1 Department of Biomedical \& Clinical Sciences (BKV), BKH/Obstetrics \& Gynaecology, \\ Faculty of Medicine and Health Sciences, Linköping University, SE-58185 Linköping, Sweden; \\ ann.josefsson@regionostergotland.se (A.J.); Gunilla.Sydsjo@regionostergotland.se (G.S.); \\ heriberto.rodriguez-martinez@liu.se (H.R.-M.) \\ 2 Department of Medicine and Optometry, Faculty of Health and Life Sciences, Linnaeus University, Hus Vita, \\ 43157 Kalmar, Sweden; ina.marteinsdottir@liu.se \\ 3 Division of Clinical Chemistry, Department of Biomedical and Clinical Sciences, \\ Faculty of Medicine and Health Sciences, Linköping University, SE-58185 Linköping, Sweden; \\ gudjon.elvar.theodorsson@liu.se \\ * Correspondence: cristina.martinez-serrano@liu.se; Tel.: +34-678077708
}

Received: 21 June 2020; Accepted: 28 July 2020; Published: 31 July 2020

check for updates

\begin{abstract}
Anxiety, chronical stress, and depression during pregnancy are considered to affect the offspring, presumably through placental dysregulation. We have studied the term placentae of pregnancies clinically monitored with the Beck's Anxiety Inventory (BAI) and Edinburgh Postnatal Depression Scale (EPDS). A cutoff threshold for BAI/EPDS of 10 classed patients into an Index group $(>10, n=23)$ and a Control group $(<10, n=23)$. Cortisol concentrations in hair (HCC) were periodically monitored throughout pregnancy and delivery. Expression differences of main glucocorticoid pathway genes, i.e., corticotropin-releasing hormone (CRH), 11ß-hydroxysteroid dehydrogenase (HSD11B2), glucocorticoid receptor (NR3C1), as well as other key stress biomarkers (Arginine Vasopressin, AVP and O-GlcNAc transferase, OGT) were explored in medial placentae using real-time qPCR and Western blotting. Moreover, gene expression changes were considered for their association with HCC, offspring, gender, and birthweight. A significant dysregulation of gene expression for CRH, AVP, and HSD11B2 genes was seen in the Index group, compared to controls, while OGT and NR3C1 expression remained similar between groups. Placental gene expression of the stress-modulating enzyme 11 $\beta$-hydroxysteroid dehydrogenase (HSD11B2) was related to both hair cortisol levels (Rho $=0.54 ; p<0.01)$ and the sex of the newborn in pregnancies perceived as stressful (Index, $p<0.05)$. Gene expression of CRH correlated with both AVP (Rho $=0.79 ; p<0.001)$ and HSD11B2 (Rho $=0.45 ; p<0.03$ ), and also between AVP with both HSD11B2 (Rho $=0.6 ; p<0.005)$ and NR3C1 (Rho $=0.56 ; p<0.03$ ) in the Control group but not in the Index group; suggesting a possible loss of interaction in the mechanisms of action of these genes under stress circumstances during pregnancy.
\end{abstract}

Keywords: antenatal stress; hair cortisol; term-placentae; RT-qPCR; human

\section{Introduction}

Antenatal maternal stress such as anxiety and depression have been widely associated with short- and long-term negative impact on the neurobiological and physiological functioning of the offspring [1-3]. Maternal distress during pregnancy and puerperium, which in Sweden has a 
$15 \%$ incidence [4-6], is apparently linked to newborns being at high risk of reduced birthweight, smaller head circumference, and adverse neurodevelopmental outcomes; including increased hypothalamic-pituitary-adrenal axis (HPA) sensitivity, anxiety, depressive-like behaviors, attention deficit, hyperactivity, poor cognitive or emotional developmental disorder, among others [7-9]. The growing morbidity among offspring born from stressed pregnancies has been related to both newborn sex and the timing of action of stressors during pregnancy. Gerardin et al. (2011), reported that sons of mothers suffering from depression during pregnancy showed deficits in the regulation of motor skills and of behavior, whereas changes of the latter were not detected in daughters [10]. Additionally, the odds for schizophrenia was higher among children born from mothers stressed at mid-pregnancy than from mothers were exposed to stressors during late pregnancy [11-13]. Stress factors during pregnancy lead to hypercortisolemia, poor reactivity, and major circadian rhythm fluctuations of cortisol [14]. Maternal cortisol passes physiologically into the fetus yet being mostly inactivated by the placenta thus avoiding deleterious effects $[15,16]$. However, from week 20 of gestation, cortisol presence induces placental production of $\mathrm{CRH}$ which increases fetal cortisol production [17]. Of interest, it is during this period when the maternal HPA-system becomes increasingly refractory to stress, so the fetus may not be as prone to fluctuations of maternal cortisol. We have recently monitored maternal cortisol during pregnancy, in primiparous and multiparous women in hair (HCC), which better reflects its overall long-time biological activity. Cortisol levels were determined as ascending during pregnancy, to dip more strongly in multiparous 3 months prior to partum compared to primiparous, thus suggesting a quicker suppression of the hypothalamic CRH production by placental CRH in multiparous women (Marteinsdottir et al., manuscript). Secretion of CRH is regulatory of several physiological processes in the fetus, from nervous system shaping to influencing delivery time and further, post-natal development [18]. However, under situations of maternal stress, placental CRH increases significantly, and can be considered a suitable biomarker for fetal distress [19]. Nonetheless, the mechanisms underlying the manifestation of these maternal stressors in the placenta need to be further investigated.

Placental mechanisms underlying stress-induced elevations in maternal glucocorticoids as a key mechanism of stress transmission to the fetus [20] remain yet unclear, in the light of other maternal systems mediating stress responses beyond the HPA-system, i.e., the arginine vasopressin/oxytocin (AVP) or the autonomic nervous (ANS) systems. Maternal stress influencing placental function via glucocorticoid (GC) act via specific receptors (NR3C1) [21,22] and the modulatory enzyme 11b-hydroxysteroid dehydrogenase type 2 (11- $\beta$-HSD-2) [15,16]; altering expression of HPA-related genes which rule the stress-modulating enzyme O-LcNAc transferase (OGT) [23].

Here, we hypothesize that perceived maternal stress during pregnancy is capable of triggering stress-related molecular signaling in term placenta which could potentially affect fetal developmental outcomes, related to offspring gender/weight. To test this hypothesis, we determined the term-placental expression of main glucocorticoid pathway genes, i.e., corticotropin-releasing hormone $(C R H)$, $11 \beta$-hydroxysteroid dehydrogenase (11 $\beta-H S D 2)$, glucocorticoid receptor (NR3C1), as well as other key stress biomarkers (Arginine Vasopressin, AVP and O-GlcNAc transferase, OGT) and their association with maternal HCC levels, offspring gender, and birth weight.

\section{Materials and Methods}

\subsection{Ethical Considerations}

The integrity of the patients has been granted by Ethical permits warranting full information prior to consent and full anonymity. Data was treated at group levels. No individual is to be identifiable in the publication. This is an established procedure in Swedish clinical investigations and it is fully described in the Ethical Perspectives in Neurology section (EPNs) permissions already obtained. All examinations and tests are harmless and have been used in several previous clinical studies. All data was treated coded and anonymously. The epidemiological surveys are already approved 
by the Human Research Ethics Committee Linköping (03-556, 07-M66 08-08-M 233-8, 2017/513-31). The study was approved by the Regional Ethical Review Board in Linköping (nr 2011/499-31 and 2013/355-32).

\subsection{Experimental Design}

A total of 390 pregnant women attending an antenatal care clinic in southeast Sweden were included in the study. The women completed anxiety and depression inventories and underwent hair cortisol collection on week 24-25, during childbirth and postpartum. Self-perceived symptoms of anxiety were assessed with the Beck's Anxiety Inventory (BAI) [24] and symptoms of depression were assessed with the Edinburgh Postnatal Depression Scale (EPDS) [25]. Both inventories are well known, easy to use, validated in Sweden [26], and often used in research settings and as screening in clinical settings [27]. As a measure of symptoms of depression and anxiety a cut off score of 10 was used for both the EPDS and the BAI. By selecting the above threshold the sensitivity for the detection of major depression was nearly $100 \%$ and the specificity $82 \%$ [28]. Women displaying pregnancy complications, including pre-eclampsia and/or preterm birth were excluded.

A total of 23 women scored $>10$ at both EPDS/BAI-indicating symptoms of depression and anxiety are here referred to as index women. A total of 23 controls who scored $<10$ on both EPDS/BAI were randomly selected from the entire study population $(n=390)$. After childbirth, the placentae were immediately collected and stored at $-80{ }^{\circ} \mathrm{C}$ until further analysis. Data on obstetric and neonatal outcomes were collected from standardized medical records. The demographic data of the patients included in this study is shown in Table 1.

Table 1. Demographic data of patients indicating symptoms of depression and anxiety (Index) and patients with no symptoms of depression nor anxiety (Control).

\begin{tabular}{cccc}
\hline & Index & Controls & \\
\hline Mean/SD & Mean/SD & $p$-Value \\
\hline Maternal age & $29.5 / 4.9$ & $28.5 / 4.2$ & 0.483 \\
BMI & $26.4 / 4.7$ & $26.6 / 5.3$ & 0.891 \\
Gestational age & $39.6 / 1.2$ & $40.0 / 1.1$ & 0.312 \\
& $\boldsymbol{n} \mathbf{( \% )}$ & $\boldsymbol{n} \mathbf{( \% )}$ & \\
\hline Ethnicity & & & 0.665 \\
Swedish & $21(91.3)$ & $19(82.6)$ & \\
Non-Swedish & $2(8.7)$ & $4(17.4)$ & NA \\
Parity & $8(34.8)$ & $8(34.8)$ & \\
Primi & $15(65.2)$ & $15(65.2)$ & 1.000 \\
Multi & & & \\
Delivery mode & $20(87.0)$ & $21(91.3)$ & \\
PN & $3(13.0)$ & $2(8.7)$ & 0.227 \\
CS or Instrumental & $16(69.6)$ & $12(52.2)$ & \\
Gender of the child & $7(30.4)$ & $11(47.8)$ & \\
Girl & &
\end{tabular}

\subsection{Hair Cortisol Concentrations (HCC)}

Hair bundles ( $3 \mathrm{~mm}$ thick $\times 3 \mathrm{~cm}$ length) were cut at scalp level from the back of the head (vertex area). The bundles were cut in one-cm segments (5-6 mg), assuming each segment reflected one-month time [29]; placed in canisters holding $2 \mathrm{~mL}$ Eppendorf tubes and frozen in liquid nitrogen $\left(\mathrm{LN}_{2}\right) \mathrm{until}$ analyzed. A competitive radioimmunoassay (RIA) was used to quantify (pg/mg) cortisol concentrations in methanol-extracted pulverized hair as described by Morelius et al. (2004) [30]. In brief, the weighed (Sartorius MC 210p microscale, Qiagen, Hilden, Germany) hair samples were pulverized (Retsch Tissue Lyser II, Haan, Germany) at $23 \mathrm{~Hz}$ for 2 min before adding $1 \mathrm{~mL}$ of methanol (Chromasolv, 
Sigma-Aldrich, Darmstadt, Germany) to extract the cortisol at RT for $10 \mathrm{~h}$. Following centrifugation (Microcentrifuge Thermo Scientific, Waltham, MA, USA, 13,000 $\mathrm{g}, 4^{\circ} \mathrm{C}$ for $1 \mathrm{~min}$ ), $800 \mu \mathrm{L}$ of the supernatant was lyophilized (SpeedVac Plus SC210A, Savant, Coral Springs, FL, USA) for at least $3 \mathrm{~h}$. The samples were dissolved in radioimmunoassay buffer and RIA-analyzed using an antiserum cross-reacting $<1 \%$ with endogenous steroids, $<40 \%$ with prednisolone and 21-deoxycortisol, and $137 \%$ with $5 \alpha$-dihydroxycortisol [31].

\subsection{Collection and Preparation of Placenta Samples}

The placentas were, immediately after expulsion, placed on ice and a $1.5-\mathrm{cm}$ square of the placental disk dissected, approximately $5-\mathrm{cm}$ apart from the insertion of the umbilical cord. This approx. $2.5-\mathrm{cm}$ thick villous parenchyma was then punched into centripetal $>1 \mathrm{~g}$ samples of the fetal (including the chorionic plate), the middle, and the maternal (including the thin basal plate) areas, snap-frozen and packed for final storage at $-80^{\circ} \mathrm{C}$.

\subsection{RNA Extraction}

Total RNA was isolated from pools of four different segments of placenta samples retrieved from the fetal side using Trizol reagent (Invitrogen, Carlsbad, CA, USA) according to the manufacturer's instructions. Briefly, tissue samples were mechanically disrupted in $1 \mathrm{~mL}$ Trizol reagent using a TissueLyser II (Qiagen, Hilden, Germany). The homogenized tissues were centrifuged at $12,000 \times g$ at $4{ }^{\circ} \mathrm{C}$ for $10 \mathrm{~min}$. Then, supernatants were incubated with bromochloropropane $(100 \mu \mathrm{L} / \mathrm{mL}$ homogenized) for $5 \mathrm{~min}$ at room temperature. Samples were then centrifuged at $12,000 \times g$ at $4{ }^{\circ} \mathrm{C}$ for $15 \mathrm{~min}$. The aqueous phases obtained were mixed with isopropanol and RNA precipitation solution (1.2 M NaCl and $0.8 \mathrm{M} \mathrm{Na}_{2} \mathrm{C}_{6} \mathrm{H}_{6} \mathrm{O}_{7}$ ) and incubated at room temperature for $10 \mathrm{~min}$. Then, samples were centrifuged at $12,000 \times \mathrm{g}$ at $4{ }^{\circ} \mathrm{C}$ for $10 \mathrm{~min}$. After discarding the supernatant, $1 \mathrm{~mL}$ of $75 \%$ ethanol was added to the pellet fraction and centrifuged at $7500 \times \mathrm{g}$ at $4{ }^{\circ} \mathrm{C}$ for $5 \mathrm{~min}$. The RNA pellets obtained were air-dried for $30 \mathrm{~min}$ and mixed with $30 \mu \mathrm{L}$ of RNase free water. The obtained total RNA was quantified with a NanoDrop ND-1000 (Thermo Fisher Scientific, Fremont, CA, USA) and quality with an Agilent 2100 Bioanalyzer (Agilent Technologies, Santa Clara, CA, USA), yielding 8-10 RNA-integrity number (RIN) values.

\subsection{Protein Extraction}

Proteins from placental samples were isolated as previously described [32]. Briefly, $200 \mu \mathrm{L}$ of RIPA buffer (Sigma-Aldrich, Darmstadt, Germany) mixed with $2 \mu \mathrm{L}$ of protein cocktail inhibitor (Thermofisher Scientific, Fremont, CA, USA) was added to each sample prior to sonication (Amplitude $50 \mathrm{~W}, 140)$. Then, samples were incubated at $4{ }^{\circ} \mathrm{C}$ for $60 \mathrm{~min}$ in rotation and later centrifugated at $13,000 \times \mathrm{g}$ at $4{ }^{\circ} \mathrm{C}$ for $10 \mathrm{~min}$. After centrifugation, the supernatants were collected and proteins were quantified using a DC Protein assay kit (Bio Rad, Hercules, CA, USA), following manufacturer's instructions. Protein suspensions were denatured by heating at $70^{\circ} \mathrm{C}$ for $10 \mathrm{~min}$ and kept at $-20^{\circ} \mathrm{C}$ until analyses.

\subsection{Relative Quantitative Reverse Transcriptase Polymerase Chain-Reaction ( $q$ RT-PCR)}

Total RNA was transcribed into cDNA using with $25 \mathrm{mM}$ dNTPs Mix, RT random primers, $20 \mathrm{U}$ of RNase inhibitor and MultiScribe Reverse Transcriptase (High Capacity cDNA Reverse Transcription Kit, Applied Biosystems, Foster City, CA, USA). The qRT-PCR was performed in $10-\mu \mathrm{L}$ reactions with $5 \mu \mathrm{L}$ of PowerUp ${ }^{\mathrm{TM}}$ SYBR $^{\mathrm{TM}}$ Green Master Mix (Applied Biosystems ${ }^{\mathrm{TM}}$, Foster City, CA, USA), $50 \mathrm{nM}$ for each set of primers, $2 \mu \mathrm{L}$ of synthetized cDNA, and water to a final volume of $10 \mu \mathrm{L}$. All reactions were carried out using the Real-Time PCR Detection System (CFX96 ${ }^{\mathrm{TM}}$; Bio-Rad Laboratories, Inc; Richmond, CA, USA). The thermal cycling profile was $50^{\circ} \mathrm{C}$ for $2 \mathrm{~min}, 95^{\circ} \mathrm{C}$ for $10 \mathrm{~min}, 40$ cycles at $95^{\circ} \mathrm{C}$ for $15 \mathrm{~s}$, and $60^{\circ} \mathrm{C}$ for $1 \mathrm{~min}$. Melt curve analysis was carried out to evaluate the specificity of each PCR reaction by detection of one single peak on the dissociation curve profile. The gene relative 
expression levels were quantified using the $\left(2^{-\Delta \Delta c t}\right)$ [33] method and GAPDH as a reference gene for cDNA normalization. Primer sequences are detailed in Table 2.

Table 2. Sequence of primers used for real-time quantitative PCR.

\begin{tabular}{lllc}
\hline \multicolumn{1}{c}{ Gene Name } & \multicolumn{1}{c}{ Primers $\left(\mathbf{5}^{\prime} \mathbf{- 3}^{\prime} \mathbf{)}\right.$} & Accession No & Amplicon Size (bp) \\
\hline \multirow{2}{*}{ CRH } & F:GAGAGAGGGAGAGAGCCTATAC & NC_00008.11 & 320 \\
& R:TGACCAAGGACTGGAAAGATG & & \\
FGT & F:GGCTGACCAGTTAGAGAAGAATAG & NC_000023.11 & 260 \\
RSD11B2 & F:TGCCTGGAATAGACTGCATAAG & & \\
& R:GGCATCTACAACTGGGGTGA & NC_000016.10 & 183 \\
GAPDH & F:GGAAGGTGAAGGTCGGAGTC & NC_000012.11 & 244 \\
$A V P$ & R:GAGGGATCTCGCTCCTGGAA & NC_000020.10 & 78 \\
$N R 3 C 1$ & Bio-Rad ID: qHsaCED0021009 & NT_02928.11 & 118 \\
\hline
\end{tabular}

\subsection{Western Blotting (WB)}

To prepare Western blots, $10 \mu \mathrm{L}(5 \mu \mathrm{g})$ of each protein suspension was loaded into 4-20\% Mini-PROTEAN ${ }^{\circledR}$ TGX ${ }^{\mathrm{TM}}$ Precast Protein Gels (BioRad, Richmond, CA, USA) and transferred to polyvinyldifluoride (PVDF) membranes (BioRad, Richmond, CA, USA). Membranes were then incubated for $1 \mathrm{~h}$ in Odyssey Blocking solution (LI-COR Biosciences, Lincoln, NE, USA) and washed $3 \times 10$ min in washing buffer (Tris-phosphate-buffered saline) containing $0.1 \%$ Tween-20 (Sigma-Aldrich, Madrid, Spain). Then, membranes were incubated at $4{ }^{\circ} \mathrm{C}$ overnight with the primary antibodies (anti-CRH; rabbit polyclonal antibody (LSBio-B11889, LSBio, Seattle, WA, USA), anti-AVP polyclonal antibody (MBS9205129, MyBiosources, San Diego, CA, USA), and anti-HSD11B2 polyclonal antibody (ab80317, abcam, Cambridge, UK) at 1:1000, 1:500, and 1:1000 dilution rate, respectively. The day after, the membranes were washed $3 \times 10 \mathrm{~min}$ and incubated for $1 \mathrm{~h}$ with the reference anti-GAPDH rabbit polyclonal primary antibody (ab181602, abcam, Cambridge, UK) at 1:10,000 dilution rate, washed again $3 \times 10 \mathrm{~min}$ and finally incubated with a secondary antibody (goat anti-rabbit IRDye $800 \mathrm{CW}$, LI-COR Biosciences, Lincoln, NE, USA) at a 1:20,000 dilution on blocking buffer. After extensive washing, the membranes were scanned (Odyssey CLx (LI-COR Biosciences, Lincoln, NE, USA), to obtain blot-images using the Image Studio 4.0 software (LI-COR Biosciences, Lincoln, NE, USA). Raw data comparisons were made only within each blot.

\subsection{Statistical Analysis}

Statistical analyses were conducted using SPSS statistical software (version 24.0; SPSS Inc., Chicago, IL, USA). Gene expression data were analyzed for normality of residuals using the Kolgomorov-Smirnov test. Since data were not normally distributed, the Mann-Whitney U-test was used to analyze the data. Protein expression data were normalized with an endogenous control and statistical significance was determined using Student's $t$-test. Associations of maternal cortisol levels with placental gene expression and associations among gene expression patterns between groups were analyzed using

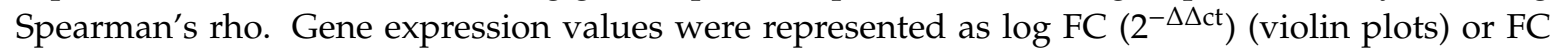
$\left(2^{-\Delta \Delta \mathrm{ct}}\right)$ (graphs). Differences were considered significant at $p<0.05$.

\section{Results}

\subsection{Prenatal Stress Influenced Gene Expression of Term-Placentas}

After qPCR analyses, the data obtained was visualized by a principal component analysis (PCA) plot, in which each data point represents an individual placenta, and each color represents a different group (Index vs. Control) (Figure 1A). The closer the data points are to each other, the more closely related the transcriptional responses are. Moreover, to gain insight into similarities among replicates, the set of genes tested by qPCR was subjected to a hierarchical clustering procedure and presented 
as heatmaps (Figure 1B). The heatmap of the selected differential gene set shows the association of the biological samples into the two distinct groups (Index vs. Control). The heat map reveals that on average, mRNA expression within placental tissues of mothers clinically diagnosed as stressed (Index) was generally higher than the control group.

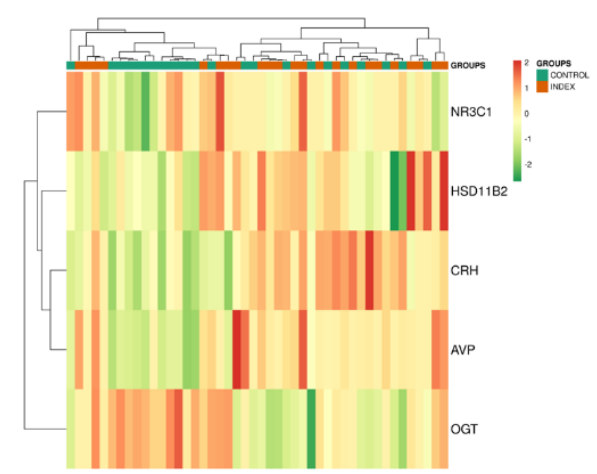

(A)

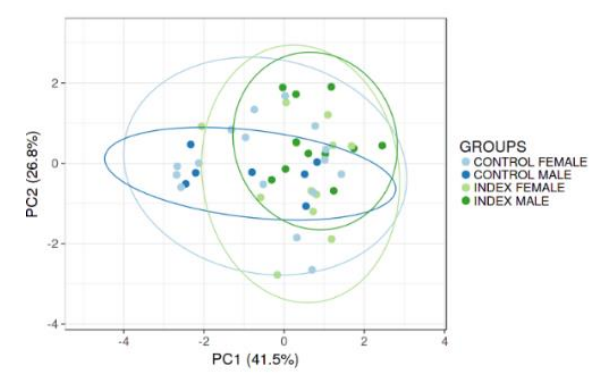

(B)

Figure 1. (A) Heat map plot of gene expression data of term-placenta samples of patients indicating symptoms of depression and anxiety (Index; $n=23$ ) and patients with no symptoms of depression or anxiety (Control, $n=23$ ). Both rows and columns are clustered using correlation distance and average linkage. Colors represent mRNA levels (red: higher, green: lower). (B) Principal component analysis (PCA) plot of gene expression data of male and female term-placenta samples of patients indicating symptoms of depression and anxiety (Index; $n=23$ ) and patients with no symptoms of depression or anxiety (Control, $n=23$ ). SVD (singular value decomposition) with imputation is used to calculate principal components. $\mathrm{X}$ and $\mathrm{Y}$ axis shows principal component 1 and principal component 2 that explain $41.5 \%$ and $26.8 \%$ of the total variance, respectively.

The qPCR analyses revealed differential gene expression between groups. Women with perceived symptoms of anxiety and depression during pregnancy had altered expression patterns for $C R H$, $H S D 11 B 2$, and $A V P$ genes in the placentas, compared to the control population. An upregulation of CRH $(p<0.05), H S D 11 B 2(p<0.05)$, and AVP $(p<0.001)$ gene expression was found in the Index group compared to the control, while OGT and NR3C1 gene expression appeared similar between groups (Figure 2).

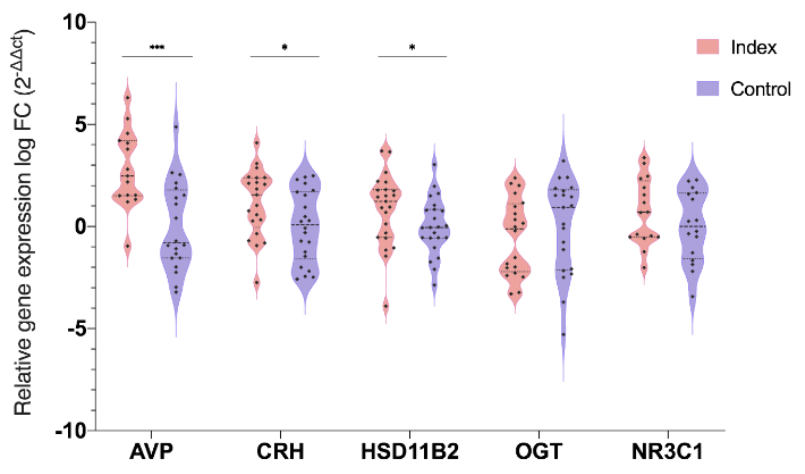

Figure 2. Differential gene expression of stress-related genes (Arginine Vasopressin- $A V P$; corticotropinreleasing hormone $-\mathrm{CRH}$; $11 \beta$-hydroxysteroid dehydrogenase-HSD11B2; O-GlcNAc transferase-OGT; glucocorticoid receptor-NR3C1) in term-placenta samples of patients indicating symptoms of depression and anxiety (Index) and patients with no symptoms of depression or anxiety. The gene names are indicated on the $\mathrm{X}$ axis and the value on the $\mathrm{Y}$ axis represents the gene expression level in the binary logarithm $(\log 2)$ value. Data are presented by violin plot showing median and inter-quartile range (Q1-Q3). Asterisks indicate significant differences among groups $\left({ }^{*} p<0.05 ;{ }^{* * *} p<0.001\right)$. 
Additionally, Spearman correlation analyses were performed to investigate the association among the expression of all genes tested in this study (Table 3). Interestingly, a significant positive correlation between $C R H$ with both AVP (Rho $=0.79 ; p<0.001$ ) and HSD11B2 (Rho = 0.45; $p<0.03$ ), and also between AVP with both HSD11B2 (Rho $=0.6 ; p<0.005$ ) and NR3C1 (Rho $=0.56 ; p<0.03$ ) gene expression in the Control group was observed. Such correlations were not evident in the Index group, suggesting a possible loss of interaction in the mechanisms of action of these genes under stress circumstances.

\subsection{Prenatal Stress Influence on Stress-Like Placental Protein Expression}

The expression of proteins related to the significantly altered genes found in this study was analyzed by Western blotting. CRH and AVP proteins were clearly detected (Figure 3A-D) with bands of 22 and $17 \mathrm{kDa}$ found in placental tissue of either Index or Control groups corresponding to CRH (anti-CRH; rabbit polyclonal antibody; LSBio-B11889) and AVP (anti-AVP polyclonal antibody; MBS9205129) proteins, respectively (Figure 3A,C,D). Significant changes in the expression of these proteins was not observed between groups. However, a trend for higher CRH protein levels in female placental samples compared to males was found following the line of CRH gene expression analyses (Figure 3B).

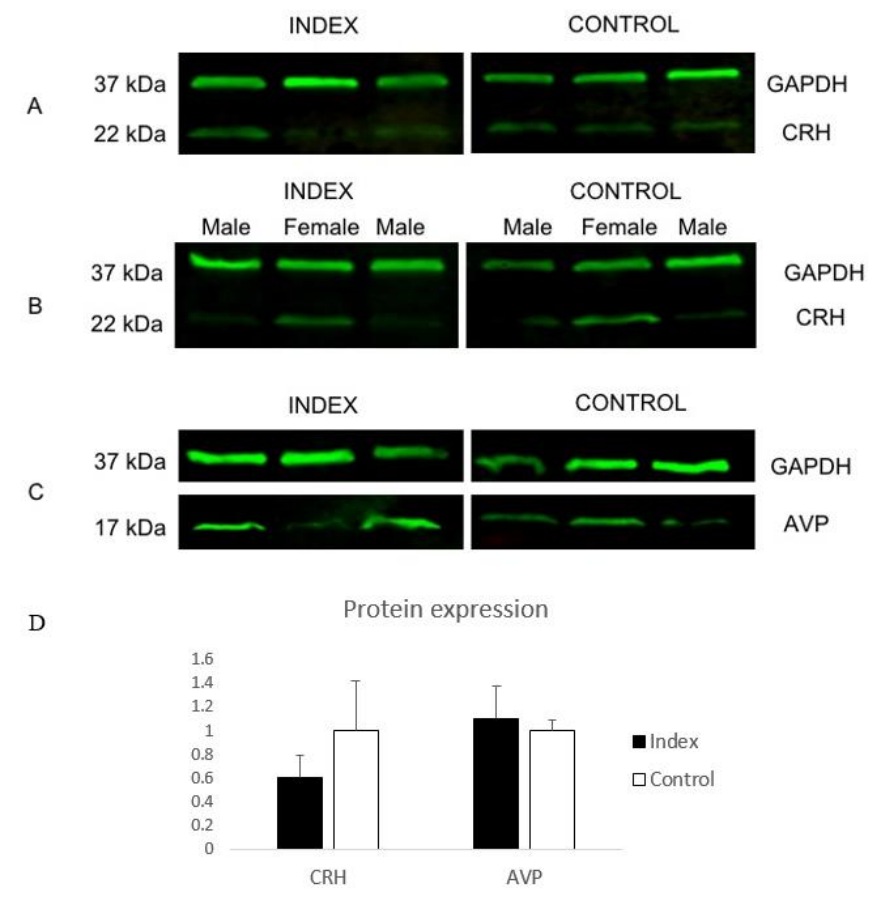

Figure 3. Western blot (WB) detection of the corticotropin-releasing hormone (CRH) and Arginine Vasopressin (AVP) proteins in term-placentas of patients indicating symptoms of depression and anxiety (Index) and patients with no symptoms of depression or anxiety (Control). (A) Human anti-CRH polyclonal antibody (LS-B11889) tested in Index and Control group and (B) between males and females identified expected bands at $22 \mathrm{kDa}$. In (C) the human anti-AVP polyclonal antibody (MBS9205129) tested in Index and Control groups identified expected bands at 17 kDA. (D) Graphical representation of protein expression of $C R H$ and $A V P$ between Index and Control groups.

\subsection{Prenatal Stress Influences the Association of Placental HSD11B2 Gene Expression with Hair Cortisol Levels}

A significant positive correlation between HSD11B2 (Rho $=0.54 ; p<0.001$ ) gene expression in term-placentas and maternal HCC-levels at parturition was found in the Index group (Table 4). This finding indicates a clear positive feedback between cortisol levels during labor and this cortisol-modulatory enzyme. 
Table 3. Spearman correlations between gene expression data of stress-related genes (corticotropin- releasing hormone-CRH; Arginine Vasopressin- $A V P$; $11 \beta$-hydroxysteroid dehydrogenase-HSD11B2; glucocorticoid receptor-NR3C1; O-GlcNAc transferase-OGT) in term-placentas of patients indicating symptoms of depression and anxiety (Index), patients with no symptoms of depression nor anxiety (Control), and all patients examined in this study (All). Comparisons showing statistical significance are marked in bold font.

\begin{tabular}{|c|c|c|c|c|c|c|c|c|c|c|c|c|}
\hline & \multicolumn{3}{|c|}{$A V P$} & \multicolumn{3}{|c|}{ HSD11B2 } & \multicolumn{3}{|c|}{ OGT } & \multicolumn{3}{|c|}{ NR3C1 } \\
\hline & Index & Control & All & Index & Control & All & Index & Control & All & Index & Control & All \\
\hline $\mathrm{CRH}$ & $\begin{array}{c}\text { Rho }=0.29 \\
p=0.3 \\
n=15\end{array}$ & $\begin{array}{c}\text { Rho }=0.79 \\
p<0.001 \\
n=20\end{array}$ & $\begin{array}{c}\text { Rho }=0.6 \\
p<0.001 \\
n=35\end{array}$ & $\begin{aligned} \text { Rho } & =-0.23 \\
p & =0.31 \\
n & =21\end{aligned}$ & $\begin{array}{c}\text { Rho }=0.45 \\
p=0.03 \\
n=22\end{array}$ & $\begin{array}{c}\text { Rho }=0.2 \\
p=0.22 \\
n=43\end{array}$ & $\begin{array}{c}\text { Rho }=-0.36 \\
p=0.12 \\
n=19\end{array}$ & $\begin{array}{c}\text { Rho }=-0.38 \\
p=0.09 \\
n=20\end{array}$ & $\begin{array}{c}\text { Rho }=-0.46 \\
p=0.003 \\
n=39\end{array}$ & $\begin{array}{c}\text { Rho }=-0.09 \\
p=0.75 \\
n=14\end{array}$ & $\begin{array}{c}\text { Rho }=0.23 \\
p=0.37 \\
n=16\end{array}$ & $\begin{array}{c}\text { Rho }=0.12 \\
p=0.52 \\
n=30\end{array}$ \\
\hline$A V P$ & & & & $\begin{array}{c}\text { Rho }=0.08 \\
p=0.76 \\
n=15\end{array}$ & $\begin{array}{c}\text { Rho }=0.6 \\
p=0.005 \\
n=20\end{array}$ & $\begin{array}{c}\text { Rho }=0.56 \\
p<0.001 \\
n=35\end{array}$ & $\begin{array}{c}\text { Rho }=-0.16 \\
p=0.57 \\
n=15\end{array}$ & $\begin{array}{c}\text { Rho }=-0.41 \\
p=0.09 \\
n=18\end{array}$ & $\begin{array}{c}\text { Rho }=-0.33 \\
p=0.06 \\
n=33\end{array}$ & $\begin{array}{c}\text { Rho }=0.007 \\
p=0.98 \\
n=12\end{array}$ & $\begin{array}{c}\text { Rho }=0.56 \\
p=0.03 \\
n=15\end{array}$ & $\begin{array}{c}\text { Rho }=0.36 \\
p=0.07 \\
n=27\end{array}$ \\
\hline HSD11B2 & & & & & & & $\begin{array}{c}\text { Rho }=0.29 \\
p=0.21 \\
n=20\end{array}$ & $\begin{array}{c}\text { Rho }=0.09 \\
p=0.69 \\
n=21\end{array}$ & $\begin{array}{c}\text { Rho }=0.11 \\
p=0.5 \\
n=41\end{array}$ & $\begin{array}{c}\text { Rho }=0.12 \\
p=0.64 \\
n=16\end{array}$ & $\begin{array}{c}\text { Rho }=0.34 \\
p=0.2 \\
n=16\end{array}$ & $\begin{array}{c}\text { Rho }=0.28 \\
p=0.12 \\
n=32\end{array}$ \\
\hline OGT & & & & & & & & & & $\begin{array}{c}\text { Rho }=0.09 \\
p=0.73 \\
n=15\end{array}$ & $\begin{array}{c}\text { Rho }=0.009 \\
p=0.97 \\
n=16\end{array}$ & $\begin{array}{c}\text { Rho }=0.008 \\
p=0.96 \\
n=31\end{array}$ \\
\hline
\end{tabular}


Table 4. Spearman correlations between maternal hair cortisol levels (at week 24-25 of pregnancy, parturition and 8 weeks postpartum), and gene expression data of stress-related genes (corticotropin-releasing hormone- $C R H$; Arginine Vasopressin-AVP; $11 \beta$-hydroxysteroid dehydrogenase-HSD11B2; glucocorticoid receptor-NR3C1; O-GlcNAc transferase-OGT) in term-placentas of patients indicating symptoms of depression and anxiety (Index), patients with no symptoms of depression nor anxiety (Control) and all patients examined in this study (All). Comparisons showing statistical significance are marked in bold font.

\begin{tabular}{|c|c|c|c|c|c|c|}
\hline GROUP & $\begin{array}{c}\text { CORTISOL } \\
\text { MEASUREMENTS }\end{array}$ & CRH & $O G T$ & HSD11B2 & $A V P$ & $N R 3 C 1$ \\
\hline \multirow{3}{*}{ Index } & Week 24-25 of pregnancy & $\begin{array}{c}\text { Rho }=0.37 \\
p=0.09 \\
n=21\end{array}$ & $\begin{array}{c}\text { Rho }=0.2 \\
p=0.38 \\
n=20\end{array}$ & $\begin{array}{c}\text { Rho }=0.021 \\
p=0.92 \\
n=23\end{array}$ & $\begin{array}{c}\text { Rho }=-0.35 \\
p=0.19 \\
n=15\end{array}$ & $\begin{array}{c}\text { Rho }=0.31 \\
p=0.24 \\
n=16\end{array}$ \\
\hline & Parturition & $\begin{array}{c}\text { Rho }=0.34 \\
p=0.12 \\
n=21\end{array}$ & $\begin{array}{c}\text { Rho }=0.02 \\
p=0.99 \\
n=20\end{array}$ & $\begin{array}{c}\text { Rho }=0.54 \\
p=0.007 \\
n=23\end{array}$ & $\begin{array}{c}\text { Rho }=0.37 \\
p=0.17 \\
n=15\end{array}$ & $\begin{array}{c}\text { Rho }=0.29 \\
p=0.27 \\
n=16\end{array}$ \\
\hline & 8 weeks Postparturition & $\begin{array}{c}\text { Rho }=0.45 \\
p=0.06 \\
n=17\end{array}$ & $\begin{array}{c}\text { Rho }=0.09 \\
p=0.72 \\
n=17\end{array}$ & $\begin{array}{c}\text { Rho }=0.29 \\
p=0.22 \\
n=19\end{array}$ & $\begin{array}{c}\text { Rho }=-0.12 \\
p=0.68 \\
n=13\end{array}$ & $\begin{array}{c}\text { Rho }=-0.24 \\
p=0.27 \\
n=15\end{array}$ \\
\hline \multirow{3}{*}{ Control } & Week $24-25$ of pregnancy & $\begin{array}{c}\text { Rho }=-0.04 \\
p=0.84 \\
n=22\end{array}$ & $\begin{aligned} \text { Rho } & =-0.19 \\
p & =0.4 \\
n & =21\end{aligned}$ & $\begin{array}{c}\text { Rho }=-0.17 \\
p=0.44 \\
n=23\end{array}$ & $\begin{array}{c}\text { Rho }=0.21 \\
p=0.36 \\
n=20\end{array}$ & $\begin{array}{c}\text { Rho }=0.171 \\
p=0.52 \\
n=16\end{array}$ \\
\hline & Parturition & $\begin{array}{c}\text { Rho }=0.03 \\
p=0.88 \\
n=22\end{array}$ & $\begin{aligned} \text { Rho } & =-0.08 \\
p & =0.7 \\
n & =20\end{aligned}$ & $\begin{array}{c}\text { Rho }=0.03 \\
p=0.87 \\
n=22\end{array}$ & $\begin{aligned} \text { Rho } & =-0.017 \\
p & =0.94 \\
n & =20\end{aligned}$ & $\begin{array}{c}\text { Rho }=0.46 \\
p=0.06 \\
n=16\end{array}$ \\
\hline & 8 weeks Postparturition & $\begin{aligned} \text { Rho } & =-0.14 \\
p & =0.5 \\
n & =19\end{aligned}$ & $\begin{array}{c}\text { Rho }=-0.32 \\
p=0.18 \\
n=19\end{array}$ & $\begin{array}{c}\text { Rho }=-0.23 \\
p=0.32 \\
n=20\end{array}$ & $\begin{array}{c}\text { Rho }=-0.27 \\
p=0.28 \\
n=17\end{array}$ & $\begin{aligned} \text { Rho } & =-0.15 \\
p & =0.6 \\
n & =14\end{aligned}$ \\
\hline \multirow{5}{*}{ All } & Week $24-25$ of pregnancy & $\begin{array}{c}\text { Rho }=0.15 \\
p=0.33 \\
n=43\end{array}$ & $\begin{array}{c}\text { Rho }=-0.05 \\
p=0.75 \\
n=41\end{array}$ & $\begin{aligned} \text { Rho } & =-0.006 \\
p & =0.96 \\
n & =46\end{aligned}$ & $\begin{array}{c}\text { Rho }=0.019 \\
p=0.91 \\
n=35\end{array}$ & $\begin{array}{c}\text { Rho }=0.24 \\
p=0.19 \\
n=32\end{array}$ \\
\hline & Parturition & $\begin{array}{c}\text { Rho }=0.17 \\
p=0.25 \\
n=43\end{array}$ & $\begin{array}{c}\text { Rho }=-0.09 \\
p=0.57 \\
n=40\end{array}$ & $\begin{array}{c}\text { Rho }=0.28 \\
p=0.054 \\
n=45\end{array}$ & $\begin{array}{c}\text { Rho }=0.044 \\
p=0.8 \\
n=35\end{array}$ & $\begin{array}{c}\text { Rho }=0.4 \\
p=0.023 \\
n=32\end{array}$ \\
\hline & 8 weeks Postparturition & $\begin{array}{c}\text { Rho }=0.04 \\
p=0.8 \\
n=36\end{array}$ & $\begin{aligned} \text { Rho } & =-0.065 \\
p & =0.71 \\
n & =36\end{aligned}$ & $\begin{array}{c}\text { Rho }=0.01 \\
p=0.94 \\
n=39\end{array}$ & $\begin{array}{c}\text { Rho }=-0.35 \\
p=0.052 \\
n=30\end{array}$ & $\begin{aligned} \text { Rho } & =-0.16 \\
p & =0.4 \\
n & =29\end{aligned}$ \\
\hline & Parturition & $\begin{array}{c}\text { Rho }=0.28 \\
p=0.07 \\
n=42\end{array}$ & $\begin{array}{c}\text { Rho }=-0.05 \\
p=0.74 \\
n=40\end{array}$ & $\begin{array}{c}\text { Rho }=-0.11 \\
p=0.45 \\
n=45\end{array}$ & $\begin{array}{c}\text { Rho }=0.08 \\
p=0.65 \\
n=34\end{array}$ & $\begin{array}{c}\text { Rho }=0.26 \\
p=0.16 \\
n=31\end{array}$ \\
\hline & 8 weeks Postparturition & $\begin{array}{c}\text { Rho }=0.23 \\
p=0.19 \\
n=31\end{array}$ & $\begin{array}{c}\text { Rho }=-0.12 \\
p=0.49 \\
n=32\end{array}$ & $\begin{array}{c}\text { Rho }=0.07 \\
p=0.66 \\
n=34\end{array}$ & $\begin{array}{c}\text { Rho }=-0.14 \\
p=0.47 \\
n=27\end{array}$ & $\begin{array}{c}\text { Rho }=0.17 \\
p=0.38 \\
n=26\end{array}$ \\
\hline
\end{tabular}




\subsection{Placental Sex Depicts Differences in the Gene Expression of HSD11B2}

The impact of offspring sex on stress-like gene expression among placental samples harvested from Index and Control women at term was further evaluated. These analyses demonstrated different responses on gene expression levels between male and female placentas (Figure 4A-E). However, only HSD11B2 showed greater $(p<0.05)$ levels of expression in males than females in the Index group (Figure 4C).

A

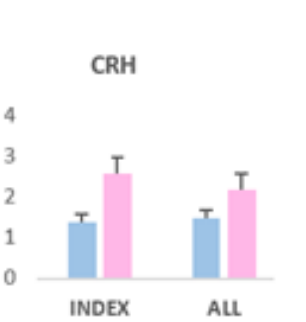

B

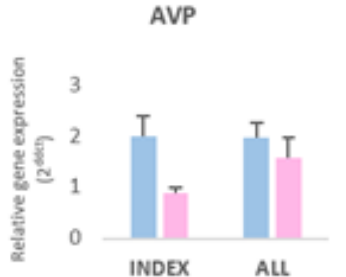

$\mathrm{C}$

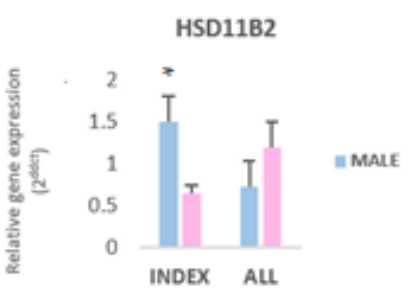

D

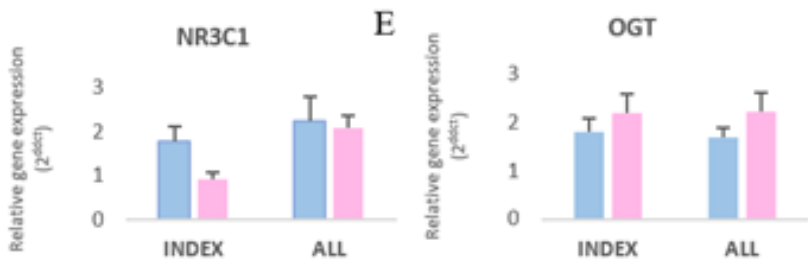

Figure 4. Differential gene expression of stress-related genes (A: corticotropin-releasing hormone- $C R H$; B: Arginine Vasopressin-AVP; C: 11ß-hydroxysteroid dehydrogenase-HSD11B2; D: glucocorticoid receptor-NR3C1; E: O-GlcNAc transferase-OGT) in male and female term-placentas of patients indicating symptoms of depression and anxiety (Index) and all patients examined. Asterisks indicate significant differences among groups $\left({ }^{*} p<0.05\right)$.

\subsection{Offspring Birth Weight (BW) and Placental Gene Expression}

In the present study the offspring BW was not affected by prenatal stress. Additionally, BW did not significantly correlate with placental gene expression in any of the groups examined (Table 5).

Table 5. Spearman correlations between offspring birth weight (BW) and gene expression data of stress-related genes (corticotropin-releasing hormone- $C R H$; Arginine Vasopressin-AVP; 11ß-hydroxysteroid dehydrogenase-HSD11B2; glucocorticoid receptor-NR3C1; O-GlcNAc transferase-OGT) in termplacentas of patients indicating symptoms of depression and anxiety (Index), patients with no symptoms of depression nor anxiety (Control), and all patients examined in this study (All).

\begin{tabular}{cccccc}
\hline \multirow{2}{*}{ BW } & \multicolumn{5}{c}{ PLACENTAL GENE EXPRESSION LEVELS AT TERM } \\
\cline { 2 - 6 } & CRH & OGT & HSD11B2 & AVP & NR3C1 \\
\hline \multirow{3}{*}{ Index } & Rho $=-0.25$ & Rho $=-0.1$ & Rho $=-0.021$ & Rho $=-0.25$ & Rho $=-0.03$ \\
& $p=0.28$ & $p=0.67$ & $p=0.93$ & $p=0.37$ & $p=0.92$ \\
& $n=21$ & $n=20$ & $n=23$ & $n=15$ & $n=16$ \\
\hline \multirow{2}{*}{ Control } & Rho $=-0.04$ & Rho $=0.25$ & Rho $=0.2$ & Rho $=0.14$ & Rho $=-0.03$ \\
& $p=0.87$ & $p=0.91$ & $p=0.36$ & $p=0.57$ & $p=0.91$ \\
& $n=22$ & $n=21$ & $n=23$ & $n=20$ & $n=16$ \\
\hline \multirow{2}{*}{ All } & Rho $=-0.18$ & Rho $=0.01$ & Rho $=0.042$ & Rho $=-0.11$ & Rho $=-0.03$ \\
& $p=0.26$ & $p=0.96$ & $p=0.78$ & $p=0.54$ & $p=0.88$ \\
& $n=43$ & $n=41$ & $n=46$ & $n=35$ & $n=32$ \\
\hline
\end{tabular}




\section{Discussion}

The current study reports the effects of maternal stress during pregnancy on gene and protein expression levels of stress-related molecules in term-placentas. Amongst the most interesting results from this study, we found that the $C R H$ gene doubled its expression in placenta samples from Index women compared to the Control group. It is known that, during pregnancy, $\mathrm{CRH}$ is responsible for preparing the environment for childbirth, thus influencing developmental trajectories towards this event. However, less is known about the gene encoding this stress-related hormone. Although it has been reported as expressed in human placenta under physiological circumstances, this is, to the best of our knowledge, the first study to report an overexpression of this gene in term-placentas under maternal stress influence. CRH is considered the central upstream mediator of stress pathway activation [34,35], and has been associated with concentration-dependent effects upon the immune system [36]. The elevation of CRH secretion in the presence of psychological stressors cause, well-before a recorded increase in glucocorticoid downstream, the release of cytokines and its associated fever [37]. Prenatal maternal stress during the first trimester is accompanied not only by $\mathrm{CRH}$ increases but also elevations of the pro-inflammatory cytokines IL-6 and TNF $\alpha$ in blood, suggesting a linkage between stress and immune activation that could potentially affect fetal programming [38,39]. In contrast, a body of evidence support the concept that $\mathrm{CRH}$ is capable of downregulating the immune system by decreasing $\mathrm{T}$ cell proliferation and natural killer (NK) cell cytotoxicity [40]. Peripherally, CRH can also act as an anti-inflammatory molecule reducing inflammatory exudate volume in various disease models [41]. Despite these apparent immunostimulant or immunosuppressive actions, the effects of CRH on the immune system are complex, and time- and tissue-specific [42,43]. While it is generally accepted that glucocorticoids suppress immune responses in the acute phase on any inflammatory process, their lengthy presence before an immune challenge can issue an inverse effect, depending on the tissue in question. For example, while chronic elevations of glucocorticoids suppress the peripheral immune system, they can promote a pro-inflammatory state on the immune cells in the brain [44]. Our findings support the notion that gene levels of placental $C R H$ increase under prenatal stress conditions and that might have an impact on subsequent immune system process in the child, thus affecting further systematic development. However, follow-up studies of relevant immune-related genes in term-placentas are required.

Moreover, the action of CRH can be potentiated by vasopressin, oxytocin, epinephrine, norepinephrine, and angiotensin II as previously reported $[45,46]$. We studied the Arginine-Vasopressin stress-hormone $(A V P)$ gene expression and its association with $C R H$ levels in at term-placental samples exposed to prenatal stress. The AVP system rules the homeostasis of vascular tonus, fluid balance, as well as the endocrine stress responses [47] through several pathways. Firstly, AVP regulates water absorption via the posterior pituitary. Secondly, AVP is critically involved in the hypothalamic-pituitary-adrenal (HPA) stress axis via the posterior pituitary and thirdly AVP, by remaining in the central nervous system, contributes to behavior and cognitive functions [48]. Furthermore, AVP is important in the control of fetoplacental blood pressure and facilitates the transition of the newborn to air breathing, cardiovascular adaptation, thermogenesis, glucose, and water homeostasis [49]. As a response to acute hypoxia the human fetus actively secretes AVP to redistribute ventricular output towards the placenta [50]. Consistent with our results, AVP shows a peak of expression under fetal "stress" circumstances, such as heat stress, leading to widespread effects on fetal cardiovascular, renal, and lung functions [51]. The marker of AVP secretion Copeptin appears increased in pre-eclampsia, both in human and murine pregnancies [52]. In pregnant mice, infusion of AVP causes hypertension and renal glomerular endotheliosis, issuing placental oxidative stress which alters placental morphology, production of placental growth factor (PGF), and placental gene expression leading to intrauterine growth restriction, all mimicking dysfunctions seen during human pre-eclampsia [53]. In the present study, we found an upregulation of placental AVP expression in Index women compared to the Control group, suggesting that not only direct fetal stress but also maternal stress during pregnancy may be capable of inducing higher levels of this stress-like hormone probably leading to placental hypoxia and 
future adverse physiological functions. Furthermore, we observed a positive significant correlation in the expression of $C R H$ and $A V P$ genes in the Control group but not in the Index group. Thus, our data support the notion that there is a positive feedback between the expression of these two genes in the placenta under physiological pregnancies which is altered under maternal-induced stress. Additionally, we found a significant increment in the gene expression of the 11- $\beta$ hydroxysteroid dehydrogenase (HSD11B2), that encodes 11ß-HSD2, the enzyme responsible for conversion of cortisol into inactive cortisone, in Index placentas compared to the Control group. Placental 11ß-HSD2 buffers the impact of maternal glucocorticoid exposure by converting cortisol/corticosterone into inactive metabolites [21,54], thus preventing the activation of glucocorticoid receptors [21,22]. However, previous studies indicate that maternal adversity including stress during pregnancy can lead to a dysfunction of this enzyme [55]. The methylation of the placental HSD11B2 concurs with a dysfunctional neurobehavior among newborns born from mothers suffering from antenatal depression or anxiety [56]. In mice, mutation of the HSD11B2 gene leads to hypertension, and increased anxiety-like behavior in adulthood [57], suggesting the regulation of placental 11ß-HSD2 function is central, linking antenatal stress with offspring morbidity long after birth. In the present study, we observed an upregulation of this gene as the levels of maternal cortisol increased during parturition in Index women, but not in the Control group, suggesting that higher levels of this enzyme are needed under stress condition in an attempt to block the transfer of cortisol within the fetal compartment.

Interestingly, HSD11B2 gene expression was positively correlated with $C R H$ and $A V P$, as well as $A V P$ gene expression was also positively correlated to the glucocorticoid receptor (NR3C1), a nuclear receptor to which cortisol binds, in the Control group but not in the Index group, suggesting a clear dysregulation of stress-related gene interactions under prenatal stress circumstances.

Additionally, while several diseases associated with prenatal stress exhibit sex bias [58], we still lack information of how antenatal stress affects placental function of male or female sex fetuses. To further investigate potential mechanisms underlying the sex-specific effect of maternal stressors on placental function, we examined whether our target genes and proteins were differently expressed depending on the sex of the offspring. Interestingly, HSD11B2 showed a significant increase in expression in male compared to female placentas in the Index group. Previous studies in rodents and humans reported that the activity and sensitivity of placental 11ßHSD2 to maternal stimuli are sex-specific $[59,60]$. A wealth of data supports that stress-like disorders are sex-biased, being more common in women than in men [61-63]. The dysregulated state of hyperarousal, which disturbs sleep and leads to concentration problems and hyperactivity, and adds to symptoms of stress, anxiety, and depression [64], is more pronounced in females than males [65,66]. In particular, a major brain arousal center, the noradrenergic locus coeruleus (LC), appears to be more activated in females than males during emotion-evoking tasks, reinforcing the statement that a stressful event may elicit a greater LC-mediated arousal response in women than in men [67]. We here suggest that, besides the evidence that biological factors can increase female vulnerability to stress and stress-related pathologies [68,69], also, females are more sensitive to the transmission of maternal stress through the placenta under the regulation of certain stress-related genes. Particularly, in normal pregnancies, placental 11 $\beta$-HSD2 activity is significantly higher in female than male fetuses [60]. However, we found a significant downregulation of the expression of this gene in female compared to male placentas in the Index group, which indicates that females might be subjected to a misfunction of the cortisol-blocking potential of this gene, thus being more exposed to a cortisol outbreak with potential developmental risks for the newborn. Although the mechanisms underlying this sex-specific pattern in maternal stress transmission are not clear, our results support the idea that males are more capable of circumventing the effects of maternal stressors by strengthening the maintenance of gene expression levels under physiological concentrations.

Overall, these findings provide novel evidence for the association of perceived maternal anxiety and depression during pregnancy and the dysregulation of placental gene expression of CRH, AVP, and HSD11B2 as potential mechanisms underlying adverse physiological and neurodevelopmental 
consequences for the newborn ultimately contributing to disease risk. Moreover, the sex-specificity of stress-related HSD11B2 gene regulation found in this study may provide new insights by which sex biases in neurodevelopmental programing occurs, leading to the identification of novel targets for therapeutic development.

Author Contributions: Conceptualization and design: I.M., A.J., G.S., E.T. and H.R.-M.; analysis: I.M. and C.A.M.; interpretation of the data: I.M., C.A.M., A.J., G.S., E.T. and H.R.-M.; original draft preparation: C.A.M. and H.R.-M.; review and editing: A.J., G.S., E.T. and H.R-M.; project administration: I.M., A.J., G.S., E.T.; funding acquisition: I.M. All authors have read and agreed to the published version of the manuscript.

Funding: This research was funded by the Medical Research Council of Southeast Sweden (FORSS proj numbers 661011, 392061, and 472721). CAM was supported by the European Union's Horizon 2020 research and innovation program under the MSCA (grant agreement No 891663).

Acknowledgments: The authors thank Lovisa Holm for punch-sampling of the placentas.

Conflicts of Interest: The authors declare no conflict of interest. The funders had no role in the design of the study; in the collection, analyses, or interpretation of data; in the writing of the manuscript, or in the decision to publish the results.

\section{References}

1. Money, K.M.; Barke, T.L.; Serezani, A.; Gannon, M.; Garbett, K.A.; Aronoff, D.M.; Mirnics, K. Gestational diabetes exacerbates maternal immune activation effects in the developing brain. Mol. Psychiatry 2018, 23, 1920-1928. [CrossRef] [PubMed]

2. Beversdorf, D.Q.; Manning, S.E.; Hillier, A.; Anderson, S.L.; Nordgren, R.E.; Walters, S.E.; Nagaraja, H.N.; Cooley, W.C.; Gaelic, S.E.; Bauman, M.L. Timing of prenatal stressors and autism. J. Autism Dev. Disord. 2005, 35, 471-478. [CrossRef] [PubMed]

3. Black, S.R.; Goldstein, B.L.; Klein, D.N. Parental depression moderates the relationships of cortisol and testosterone with children's symptoms. J. Affect. Disord. 2019, 251, 42-51. [CrossRef] [PubMed]

4. Sydsjo, G.; Agnafors, S.; Bladh, M.; Josefsson, A. Anxiety in women - a Swedish national three-generational cohort study. BMC Psychiatry 2018, 18, 168. [CrossRef] [PubMed]

5. Josefsson, A.; Vikstrom, J.; Bladh, M.; Sydsjo, G. Major depressive disorder in women and risk for future generations: Population-based three-generation study. BJPsych open 2019, 5, e8. [CrossRef]

6. Lilliecreutz, C.; Laren, J.; Sydsjo, G.; Josefsson, A. Effect of maternal stress during pregnancy on the risk for preterm birth. BMC Pregnancy Childbirth 2016, 16, 5. [CrossRef]

7. Emack, J.; Kostaki, A.; Walker, C.-D.; Matthews, S.G. Chronic maternal stress affects growth, behaviour and hypothalamo-pituitary-adrenal function in juvenile offspring. Horm. Behav. 2008, 54, 514-520. [CrossRef]

8. Li, J.; Yang, H.; Guldin, M.-B.; Vedsted, P.; Vestergaard, M. Increased utilisation of primary healthcare in persons exposed to severe stress in prenatal life: A national population-based study in Denmark. BMJ Open 2015, 5, e005657. [CrossRef]

9. Grizenko, N.; Shayan, Y.R.; Polotskaia, A.; Ter-Stepanian, M.; Joober, R. Relation of maternal stress during pregnancy to symptom severity and response to treatment in children with ADHD. J. Psychiatry Neurosci. 2008, 33, 10-16.

10. Gerardin, P.; Wendland, J.; Bodeau, N.; Galin, A.; Bialobos, S.; Tordjman, S.; Mazet, P.; Darbois, Y.; Nizard, J.; Dommergues, M.; et al. Depression during pregnancy: Is the developmental impact earlier in boys? A prospective case-control study. J. Clin. Psychiatry 2011, 72, 378-387. [CrossRef]

11. Huttunen, M.O.; Niskanen, P. Prenatal loss of father and psychiatric disorders. Arch. Gen. Psychiatry 1978, 35, 429-431. [CrossRef]

12. Gao, Y.; Hyttel, P.; Hall, V.J. Regulation of H3K27me3 and H3K4me3 during early porcine embryonic development. Mol. Reprod. Dev. 2010, 77, 540-549. [CrossRef]

13. Ellman, L.M.; Schetter, C.D.; Hobel, C.J.; Chicz-Demet, A.; Glynn, L.M.; Sandman, C.A. Timing of fetal exposure to stress hormones: Effects on newborn physical and neuromuscular maturation. Dev. Psychobiol. 2008, 50, 232-241. [CrossRef]

14. Spiga, F.; Zhao, Z.; Lightman, S.L. Prolonged treatment with the synthetic glucocorticoid methylprednisolone affects adrenal steroidogenic function and response to inflammatory stress in the rat. Brain. Behav. Immun. 2020. [CrossRef] 
15. Florio, P.; Severi, F.M.; Ciarmela, P.; Fiore, G.; Calonaci, G.; Merola, A.; De Felice, C.; Palumbo, M.; Petraglia, F. Placental stress factors and maternal-fetal adaptive response: The corticotropin-releasing factor family. Endocrine 2002, 19, 91-102. [CrossRef]

16. Sandman, C.A.; Glynn, L.; Wadhwa, P.D.; Chicz-DeMet, A.; Porto, M.; Garite, T. Maternal hypothalamic-pituitary-adrenal disregulation during the third trimester influences human fetal responses. Dev. Neurosci. 2003, 25, 41-49. [CrossRef]

17. Cheng, Y.H.; Nicholson, R.C.; King, B.; Chan, E.C.; Fitter, J.T.; Smith, R. Corticotropin-releasing hormone gene expression in primary placental cells is modulated by cyclic adenosine $3^{\prime}, 5^{\prime}$-monophosphate. J. Clin. Endocrinol. Metab. 2000, 85, 1239-1244. [CrossRef]

18. Vannuccini, S.; Bocchi, C.; Severi, F.M.; Challis, J.R.; Petraglia, F. Endocrinology of human parturition. Ann. Endocrinol. 2016, 77, 105-113. [CrossRef]

19. Sandman, C.A. Prenatal CRH: An integrating signal of fetal distress. Dev. Psychopathol. 2018, 30, 941-952. [CrossRef]

20. Ghaemmaghami, P.; Dainese, S.M.; La Marca, R.; Zimmermann, R.; Ehlert, U. The association between the acute psychobiological stress response in second trimester pregnant women, amniotic fluid glucocorticoids, and neonatal birth outcome. Dev. Psychobiol. 2014, 56, 734-747. [CrossRef]

21. Benediktsson, R.; Calder, A.A.; Edwards, C.R.; Seckl, J.R. Placental 11 beta-hydroxysteroid dehydrogenase: A key regulator of fetal glucocorticoid exposure. Clin. Endocrinol. 1997, 46, 161-166. [CrossRef]

22. Seckl, J.R.; Meaney, M.J. Glucocorticoid programming. Ann. N. Y. Acad. Sci. 2004, 1032, 63-84. [CrossRef]

23. Howerton, C.L.; Morgan, C.P.; Fischer, D.B.; Bale, T.L. O-GlcNAc transferase (OGT) as a placental biomarker of maternal stress and reprogramming of CNS gene transcription in development. Proc. Natl. Acad. Sci. USA 2013, 110, 5169-5174. [CrossRef]

24. Beck, A.T.; Epstein, N.; Brown, G.; Steer, R.A. An inventory for measuring clinical anxiety: Psychometric properties. J. Consult. Clin. Psychol. 1988, 56, 893-897. [CrossRef]

25. Cox, J.L.; Holden, J.M.; Sagovsky, R. Detection of postnatal depression. Development of the 10-item Edinburgh Postnatal Depression Scale. Br. J. Psychiatry 1987, 150, 782-786. [CrossRef]

26. Rubertsson, C.; Borjesson, K.; Berglund, A.; Josefsson, A.; Sydsjo, G. The Swedish validation of Edinburgh Postnatal Depression Scale (EPDS) during pregnancy. Nord. J. Psychiatry 2011, 65, 414-418. [CrossRef]

27. Josefsson, A.; Berg, G.; Nordin, C.; Sydsjö, G. Prevalence of depressive symptoms in late pregnancy and postpartum. Acta Obstet. Gynecol. Scand. 2001, 80, 251-255. [CrossRef]

28. Harris, B.; Huckle, P.; Thomas, R.; Johns, S.; Fung, H. The use of rating scales to identify post-natal depression. Br. J. Psychiatry 1989, 154, 813-817. [CrossRef]

29. Wennig, R. Potential problems with the interpretation of hair analysis results. Forensic Sci. Int. 2000, 107, 5-12. [CrossRef]

30. Morelius, E.; Nelson, N.; Theodorsson, E. Salivary cortisol and administration of concentrated oral glucose in newborn infants: Improved detection limit and smaller sample volumes without glucose interference. Scand. J. Clin. Lab. Invest. 2004, 64, 113-118. [CrossRef]

31. Karlén, J.; Ludvigsson, J.; Frostell, A.; Theodorsson, E.; Faresjö, T. Cortisol in hair measured in young adults a biomarker of major life stressors? BMC Clin. Pathol. 2011, 11, 12. [CrossRef]

32. Alvarez-Rodriguez, M.; Vicente-Carrillo, A.; Rodriguez-Martinez, H. Hyaluronan improves neither the long-term storage nor the cryosurvival of liquid-stored CD44-bearing AI boar spermatozoa. J. Reprod. Dev. 2018, 64, 351-360. [CrossRef]

33. Livak, K.J.; Schmittgen, T.D. Analysis of relative gene expression data using real-time quantitative PCR and the 2(-Delta Delta C(T)) Method. Methods 2001, 25, 402-408. [CrossRef]

34. Bale, T.L.; Vale, W.W. CRF and CRF receptors: Role in stress responsivity and other behaviors. Annu. Rev. Pharmacol. Toxicol. 2004, 44, 525-557. [CrossRef]

35. Tan, H.; Zhong, P.; Yan, Z. Corticotropin-releasing factor and acute stress prolongs serotonergic regulation of GABA transmission in prefrontal cortical pyramidal neurons. J. Neurosci. 2004, 24, 5000-5008. [CrossRef]

36. Black, P.H. Central nervous system-immune system interactions: Psychoneuroendocrinology of stress and its immune consequences. Antimicrob. Agents Chemother. 1994, 38, 1-6. [CrossRef]

37. Morrow, L.E.; McClellan, J.L.; Conn, C.A.; Kluger, M.J. Glucocorticoids alter fever and IL-6 responses to psychological stress and to lipopolysaccharide. Am. J. Physiol. 1993, 264, R1010-6. [CrossRef] 
38. Bronson, S.L.; Bale, T.L. Prenatal stress-induced increases in placental inflammation and offspring hyperactivity are male-specific and ameliorated by maternal antiinflammatory treatment. Endocrinology 2014, 155, 2635-2646. [CrossRef]

39. Monk, C.; Feng, T.; Lee, S.; Krupska, I.; Champagne, F.A.; Tycko, B. Distress During Pregnancy: Epigenetic Regulation of Placenta Glucocorticoid-Related Genes and Fetal Neurobehavior. Am. J. Psychiatry 2016, 173, 705-713. [CrossRef]

40. Pawlikowski, M.; Zelazowski, P.; Dohler, K.; Stepien, H. Effects of two neuropeptides, somatoliberin (GRF) and corticoliberin (CRF), on human lymphocyte natural killer activity. Brain. Behav. Immun. 1988, 2, 50-56. [CrossRef]

41. Karalis, K.; Crofford, L.; Wilder, R.L.; Chrousos, G.P. Glucocorticoid and/or glucocorticoid antagonist effects in inflammatory disease-susceptible Lewis rats and inflammatory disease-resistant Fischer rats. Endocrinology 1995, 136, 3107-3112. [CrossRef]

42. Karalis, K.; Muglia, L.J.; Bae, D.; Hilderbrand, H.; Majzoub, J.A. CRH and the immune system. J. Neuroimmunol. 1997, 72, 131-136. [CrossRef]

43. You, X.; Liu, J.; Xu, C.; Liu, W.; Zhu, X.; Li, Y.; Sun, Q.; Gu, H.; Ni, X. Corticotropin-releasing hormone (CRH) promotes inflammation in human pregnant myometrium: The evidence of $\mathrm{CRH}$ initiating parturition? J. Clin. Endocrinol. Metab. 2014, 99, E199-E208. [CrossRef] [PubMed]

44. Sorrells, S.F.; Sapolsky, R.M. An inflammatory review of glucocorticoid actions in the CNS. Brain. Behav. Immun. 2007, 21, 259-272. [CrossRef] [PubMed]

45. Bilezikjian, L.M.; Vale, W.W. Regulation of ACTH secretion from corticotrophs: The interaction of vasopressin and CRF. Ann. N. Y. Acad. Sci. 1987, 512, 85-96. [CrossRef]

46. Faucher, D.J.; Laptook, A.R.; Parker, C.R.; Porter, J.C.; Rosenfeld, C.R. Increased fetal secretion of ACTH and cortisol by arginine vasopressin. Am. J. Physiol. 1988, 254, R410-6. [CrossRef] [PubMed]

47. Christ-Crain, M.; Fenske, W. Copeptin in the diagnosis of vasopressin-dependent disorders of fluid homeostasis. Nat. Rev. Endocrinol. 2016, 12, 168-176. [CrossRef]

48. Evers, K.S.; Wellmann, S. Arginine Vasopressin and Copeptin in Perinatology. Front. Pediatr. 2016, 4, 75. [CrossRef]

49. Chard, T.; Hudson, C.N.; Edwards, C.R.; Boyd, N.R. Release of oxytocin and vasopressin by the human foetus during labour. Nature 1971, 234, 352-354. [CrossRef]

50. Oosterbaan, H.P.; Swaab, D.F. Amniotic oxytocin and vasopressin in relation to human fetal development and labour. Early Hum. Dev. 1989, 19, 253-262. [CrossRef]

51. Smith, J.; Halse, K.G.; Damm, P.; Lindegaard, M.L.; Amer-Wahlin, I.; Hertel, S.; Johansen, M.; Mathiesen, E.R.; Nielsen, L.B.; Goetze, J.P. Copeptin and MR-proADM in umbilical cord plasma reflect perinatal stress in neonates born to mothers with diabetes and MR-proANP reflects maternal diabetes. Biomark. Med. 2013, 7 , 139-146. [CrossRef]

52. Sandgren, J.A.; Deng, G.; Linggonegoro, D.W.; Scroggins, S.M.; Perschbacher, K.J.; Nair, A.R.; Nishimura, T.E.; Zhang, S.Y.; Agbor, L.N.; Wu, J.; et al. Arginine vasopressin infusion is sufficient to model clinical features of preeclampsia in mice. JCI insight 2018, 3. [CrossRef]

53. Scroggins, S.M.; Santillan, D.A.; Lund, J.M.; Sandgren, J.A.; Krotz, L.K.; Hamilton, W.S.; Devor, E.J.; Davis, H.A.; Pierce, G.L.; Gibson-Corley, K.N.; et al. Elevated vasopressin in pregnant mice induces T-helper subset alterations consistent with human preeclampsia. Clin. Sci. 2018, 132, 419-436. [CrossRef]

54. Staud, F.; Mazancova, K.; Miksik, I.; Pavek, P.; Fendrich, Z.; Pacha, J. Corticosterone transfer and metabolism in the dually perfused rat placenta: Effect of 11beta-hydroxysteroid dehydrogenase type 2. Placenta 2006, 27, 171-180. [CrossRef]

55. Sarkar, S.; Tsai, S.W.; Nguyen, T.T.; Plevyak, M.; Padbury, J.F.; Rubin, L.P. Inhibition of placental 11beta-hydroxysteroid dehydrogenase type 2 by catecholamines via alpha-adrenergic signaling. Am. J. Physiol. Regul. Integr. Comp. Physiol. 2001, 281, R1966-74. [CrossRef]

56. Conradt, E.; Lester, B.M.; Appleton, A.A.; Armstrong, D.A.; Marsit, C.J. The roles of DNA methylation of NR3C1 and 11beta-HSD2 and exposure to maternal mood disorder in utero on newborn neurobehavior. Epigenetics 2013, 8, 1321-1329. [CrossRef]

57. Marsit, C.J.; Maccani, M.A.; Padbury, J.F.; Lester, B.M. Placental 11-beta hydroxysteroid dehydrogenase methylation is associated with newborn growth and a measure of neurobehavioral outcome. PLoS One 2012, 7, e33794. [CrossRef] 
58. Barke, T.L.; Money, K.M.; Du, L.; Serezani, A.; Gannon, M.; Mirnics, K.; Aronoff, D.M. Sex modifies placental gene expression in response to metabolic and inflammatory stress. Placenta 2019, 78, 1-9. [CrossRef]

59. Wilcoxon, J.S.; Schwartz, J.; Aird, F.; Redei, E.E. Sexually dimorphic effects of maternal alcohol intake and adrenalectomy on left ventricular hypertrophy in rat offspring. Am. J. Physiol. Endocrinol. Metab. 2003, 285, E31-E39. [CrossRef]

60. Murphy, V.E.; Gibson, P.G.; Giles, W.B.; Zakar, T.; Smith, R.; Bisits, A.M.; Kessell, C.G.; Clifton, V.L. Maternal asthma is associated with reduced female fetal growth. Am. J. Respir. Crit. Care Med. 2003, 168, 1317-1323. [CrossRef]

61. Sheikh, J.I.; Leskin, G.A.; Klein, D.F. Gender differences in panic disorder: Findings from the National Comorbidity Survey. Am. J. Psychiatry 2002, 159, 55-58. [CrossRef]

62. Kessler, R.C.; Petukhova, M.; Sampson, N.A.; Zaslavsky, A.M.; Wittchen, H.-U. Twelve-month and lifetime prevalence and lifetime morbid risk of anxiety and mood disorders in the United States. Int. J. Methods Psychiatr. Res. 2012, 21, 169-184. [CrossRef]

63. Breslau, N. Gender differences in trauma and posttraumatic stress disorder. J. Gend. Specif. Med. 2002, 5, 34-40.

64. Palagini, L.; Moretto, U.; Novi, M.; Masci, I.; Caruso, D.; Drake, C.L.; Riemann, D. Lack of Resilience Is Related to Stress-Related Sleep Reactivity, Hyperarousal, and Emotion Dysregulation in Insomnia Disorder. J. Clin. sleep Med. JCSM Off. Publ. Am. Acad. Sleep Med. 2018, 14, 759-766. [CrossRef]

65. Plante, D.T.; Landsness, E.C.; Peterson, M.J.; Goldstein, M.R.; Riedner, B.A.; Wanger, T.; Guokas, J.J.; Tononi, G.; Benca, R.M. Sex-related differences in sleep slow wave activity in major depressive disorder: A high-density EEG investigation. BMC Psychiatry 2012, 12, 146. [CrossRef]

66. Kokras, N.; Dalla, C. Preclinical sex differences in depression and antidepressant response: Implications for clinical research. J. Neurosci. Res. 2017, 95, 731-736. [CrossRef]

67. Kobayashi, I.; Mellman, T.A. Gender differences in sleep during the aftermath of trauma and the development of posttraumatic stress disorder. Behav. Sleep Med. 2012, 10, 180-190. [CrossRef]

68. Bangasser, D.A.; Valentino, R.J. Sex differences in stress-related psychiatric disorders: Neurobiological perspectives. Front. Neuroendocrinol. 2014, 35, 303-319. [CrossRef]

69. Bangasser, D.A.; Eck, S.R.; Telenson, A.M.; Salvatore, M. Sex differences in stress regulation of arousal and cognition. Physiol. Behav. 2018, 187, 42-50. [CrossRef]

(C) 2020 by the authors. Licensee MDPI, Basel, Switzerland. This article is an open access article distributed under the terms and conditions of the Creative Commons Attribution (CC BY) license (http://creativecommons.org/licenses/by/4.0/). 